\title{
Attitudes of young Indian consumers towards luxury brands
}

\author{
Dr. R. Srinivasan, Dr. R.K. Srivastava \& Prof. Sandeep Bhanot
}

\section{Introduction:}

1.1 Luxury brands: Luxury is no longer restricted today to only the rich and the selected few but is being used for mass marketing now. The concept of luxury has been changing dramatically across time and culture. Earlier, luxury was connected with things like wines, champagne, designer clothes and sports cars. These days, people have become richer and luxury is a blurred genre that is no longer the preserve of the elite. More and more consumers have increased their financial status as the old values of tradition and nobility have become less important. People are having much more disposable income in comparison to earlier generations, resulting in a tendency towards fulfilling personal needs and aspirations through experience. Therefore, it could be said that luxury is more about experience (Yeoman and McMahon-Beattie, 2010), rather than financial value. This is not to say that luxury is about status, but luxury is more than financial value. Indeed, they run hand in hand. The need for personal gratification and aspirations has led to greater emphasis on having things which make life better and easy. It means that consumers want to improve their life. This is what Danziger (2005) and Israel (2003) mean when they say that luxury is not just restricted to trophies and status symbols but also covers things giving aesthetic experience and indulgence. This is also due to increasing purchasing power of women in society, which is a good sign for luxury markets such as wellbeing, clothes and tourism. We see that the earlier concept of luxury of consumption and elitism stills prevails especially in emerging economies of China. In the recent times, the Global Financial Crisis has led consumers to re-examine their priorities and as a consequence, attitudes and behaviors towards luxury have changed.

In management field it is accepted to distinguish luxury products from necessary and ordinary products within their category by their basic characteristics. These include things like financial value, quality, aesthetics, exclusivity and status giving. All of these characteristics are relative terms. A luxury product is characterised by a relatively high rating on each of these dimensions compared to other products of its category (Trommsdorff and Heine 2008, p. 1670). Luxury brands are those whose ratio of functional utility to price is low while the ratio of intangible and situational utility to price is high.

1.2 Indian luxury market: Although in the last few years, India's luxury industry has witnessed a significant transformation, but the concept of luxury is not new for India. India was known for its prosperity before the British came to India. Even later, there were many royal families and business classes which were buyers of western luxury brands. In addition, India has been a production outsourcing destination for a long time, but at present due to a steadily growing economy and globalized business environment. India has rapidly transformed into a huge market for luxury products. The luxury market showed a high growth of 20 percent in the year 2009 and reached USD 5.75 billion in 2010. In 2012, luxury products have grown at 29 percent to reach a size of USD 2.05 billion, well above expectation of 23 percent. Services have grown at 22 percent to reach USD 0.95 billion and assets have grown at 13 percent to reach USD 2.75 billion. According to a recent report by Technopak, out of the $\$ 2.5$ billion luxury market in India, luxury products and services constitute around 15 percent. It is also estimated that the luxury market in India is set to touch almost three times its current size at USS 14.72 billion by 2015 (A T Kearney, 2011). As said by the industry experts, this growth is due to continuous increases in high net worth individuals (More than 150000) with a net worth of $\$ 600$ billion and more than three million household earning above Rs. 10 Lakh in the top 10 cities in India.

1.3 Indian luxury consumer: Many demographic changes have taken place in the Indian population which have led to increase in purchase of luxury brands. After the advent of globalization, the youth have better job opportunities and higher disposable incomes which has increased their purchasing power. It is assumed that the young have less of liabilities at the start of their career and thus are high on materialism which drives consumerism among them. This had elevated the consumption pattern to conspicuous level.

According to Narayan (2012), the Indian luxury shopper can be categorized into the following segments:

(i) Richie Rustie: These are people who do not follow any set patterns and defy stereotyping. They buy luxury brands for no fixed reasons and so it is difficult to fit them into any segment.

(ii) Vivacious Vivant: This comprise of self- made entrepreneurs or professional business executives who want to spend money to enjoy life, without feeling guilty. They work hard so that they can achieve success and celebrate it by buying luxury brands.

(iii) Political Prowler: They want to acquire anything new with the money they have. Acquisitive to the core, has a childlike mentality of coveting whatever they sees new. The source of their riches can be unclear but they contribute the maximum to the purchase of luxury brands. 
(iv) Affluent Ascetic: These are very rich and want value for money. So they may buy Jimmy Choo shoes and at the same time they are not embarrassed about buying Kolhapuri chappals. They buy luxury products only when they satisfy their needs.

(v)Classy Connoisseur: These are ultra- high net worth individuals and purchase luxury products for their intrinsic satisfaction. For them, luxury is a part of day-to-day life and have a style of their own.

(vi) Flashy Flaunter: They buy luxury brands to achieve status in society and so they look for luxury products where luxury is visible in the form of logos. So they buy luxury products like watches and cars but will not buy luxury products where luxury is not seen such as lingerie and high quality kitchen and bathroom fittings.

\section{Literature Review:}

2.1 Luxurybrands: The concept of luxury is complex and subjective and its meaning is dependent on various personal and interpersonal motives (Vigneron \& Johnson 2004). In order to understand the meaning of luxury, we can first describe the nature of luxury, luxury goods, luxury brands and brand equity for luxury brands.

The word luxury has been derived from the Latin words "luxus" and "luxuria" (Roux and Floch 1996). As per the meaning given in dictionaries, luxury means extravagance, opulence (UBC Sunsite n.d.), and rankness (University of Notre Dame n.d.). The word luxury should have a positive value of splendour to it. However, it takes on the negative meaning of decadence when used in association with "private" and "excess", and put into a social context (Roux and Floch 1996). Luxury can be seen as a way of life.

Bourne (1957) defined luxury goods as exclusive products which are not so commonly owned or used. But they are more visible and symbolic than necessity products. They are mainly branded goods which are bought so that they can satisfy the psychological needs of the consumer and also lead to an increase of selfesteem. Such products are purchased mainly for social and individual needs rather than functional needs which play a secondary role in purchase decisions (Arghavan and Zaichkowsky 2000).

Roux \& Floch (1996) say that luxury is not just about price, but also associated with pleasure, refinement, exclusivity and appreciation. A luxury product is also characterised by very limited supply and recognition of value by other people.

Kapferer (1997, p.253; as cited in Vigneron and Johnson 2004) summarised luxury as defining beauty, enlightening and providing good taste. According to him, luxury products provide sensory pleasure and is the appendage of the ruling or elite classes.

Luxury brands can also be described as premium or high priced brands that consumers purchase to satisfy their psychological needs like materialistic, hedonic and social needs rather than for their economical and functional value (Nueno and Quelch 1998). Thus, luxury brands can be characterised as those which are conspicuous, unique and provide high social and emotional value and are of excellent quality (as explained by Vigneron and Johnson 1999). Since people interact with each other at a different personal and social level, they will develop different perceptions of luxury brands. Hence, the definition of luxury brands varies according to motivations and values leading to purchase of luxury brands. The main factors leading to the purchase of luxury brands are the need for sociability and self-expression (Vigneron and Johnson 1999).

Dubois, Laurent and Czellar (2001) proposed a definition of the nature and characteristics of the concept of luxury, and identified six properties of luxury products: 1) excellent quality, 2) premium pricing, 3) exclusivity, rarity and uniqueness, 4) aesthetics and good looks 5) ancestral heritage and 6) superfluousness.

By tradition, individuals consume luxury goods because they want to differentiate themselves (Baudrillard 1968; Baudrillard 1970) by becoming a part of their reference group, or they want to distinguish themselves from other groups to show that they are a part of a higher social class. The elites or the upper social classes purchased luxury goods to segregate themselves from the working class that consumed necessity goods (Bourdieu, 1979). These upper classes purchased luxury goods not for their economic value but for their social status value. This "Affluent" segment (Stanley 1989) was differentiated into "Old money" (Aldrich 1988; Hirschman 1988) and "Nouveaux Riches" (LaBarbera 1988). The "Affluent" basically buy luxury goods all the time to satisfy their needs for material immortality (Hirschman 1990), it is a lifestyle choice for them. The "Excluded", represented the majority of the population, and did not have access to luxury (Dubois and Laurent 1995).

Although luxury is a term that we all know and use in our life, how "luxury" is defined depends on each one's perceptions. Previous studies did also not reach high consistency regarding what luxury is about. Berry (1994) characterizes luxury goods as items that rise desire and provide pleasure to its consumers. Also the concept of rarity and exclusivity has not been forgotten, being highlighted by Pantzalis (1995). Kapferer (1997) says that luxury exhibits beauty and aesthetics and can be applied to functional items. He also says that luxury has an enlightening effect and provides sensory pleasure. Nia and Zaichkowsky (2000) argue that luxury goods enable consumers to satisfy their functional and psychological needs, and that this is what makes the distinction between luxury and non-luxury goods, as non-luxury goods do not fulfil the psychological need because they are not able to provide esteem to its owners. Phau and Prendergast (2000) argue that luxury goods are those 
which exhibit exclusivity, brand image and identity, brand awareness and excellent in the minds of the consumers. Webster (2002) defines it simply as "non-essential items". Cornell (2002) says that luxury can be characterised by a strong element of human involvement, scarcity or limited supply and value recognition by others. On the other hand, McKinsey (1990) and Wiedmann, Hennings, and Siebels( 2009) sates that luxury goods are the ones that have the higher ratio of price-quality. Finally, Kapferer and Bastien (2008) argue that "luxury is qualitative and not quantitative" and is when "hedonism takes over functionality" as it has to be "multi-sensory and experiential" to each consumer. Thus, both authors claim that luxury is only a true luxury when some part of it is handmade and the brand has the capacity to provide exclusive services to their consumers.

Thus, it seems that luxury is seen in very diverse ways by different authors. In this study, we opted to use our own definition shaped from a mix of the definitions transcript above. Our proposal of definition states that luxury is either a service or a good that is able to fill both functional and psychological needs of the consumer (Nia and Zaichkowsky 2000). Hence, the service and/or good has to be able to transmit to the customer extra pleasure (Kapferer 1997) and a truly multi-sensorial experience (Kapferer and Bastien 2008), as consumers are increasingly seeking more personal fulfilment and aspiration through experience (Yeoman, McMahon-Beatie and Brown 2005 \& Yeoman and Mc-Mahon-Beattie 2006). Luxury goods should present a high level of perceived quality (Phau and Prendergast 2000), as a high price (McKinsey 1990) and also a limited supply (Cornell 2002, p.47) to ensure the exclusivity and rarity required by customers (Pantzalis 1995; Phau and Prendergast 2000). Finally, we believe that luxury goods have to have some part of it handmade and that the brand has to be able to answer to customer's wishes and needs with special and customized offers (Kapferer and Bastien 2008).

According to Phau and Prendergast (2000), luxury represents much more nowadays; one of the most significant changes is that it is on necessarily expensive, but by no means is it a necessity (Brannen, 1996). Within the literature on luxury, McKinsey (1990) and Nueno \& Quelch (1998) defined luxury by the use of price and quality ratio. Whatever falls into the highest price and quality ratio category is regarded as luxury. This definition is in line with that of Berry's (1994) who has put forward that luxury is an expenditure that goes beyond what is necessary and he asserts that luxuries are not required( Berry, 1994, p.23). Many researchers feel that defining the term is rather complicated and that the perception of the luxury concept takes on different forms and depend on two main subjects: the context and people concerned (Campbell, 1987). Vigneron \& Johnson (2004) attempted to explain the complication of defining the term, saying that human involvement, limited supply, and recognition of value are the main constituents (Berry, 1994). Therefore, luxury is often considered as a subjective matter.

Luxury products help to satisfy a consumer's functional needs and also fulfil him/her psychologically (Dubois, Czellar \& Laurent, 2001). A particular good can be desired as a luxury only if the ownership of the goods is able to provide pleasure (Berry, 1994). In addition, luxuries are by definition always out of the reach of mass consumption (Berry, 1994) and exclusivity and rarity are therefore features connected to the concept of luxury (Pantzalis, 1995).

As discussed previously, the consumption of luxury itself is influenced by several aspects. Therefore, it is reasonable to claim that it is subjective and multidimensional (Brannen, 1992). Given this reason, an integrative understanding of luxury is compulsory in order to define it (Berry, 1994). Vigneron and Johnson (1993) suggested the definition of luxury as "highest level of prestigious brands which are able to provide several physical and psychological values" (as explained by Berry, 1994, p.126).

From an Indian perspective, the people want value for money and they purchase luxury goods for selfidentity and well-being. Purchasing certain branded luxury goods help them to display their own tastes and values. For some it serves to fulfil the emotional needs where they see luxury as an indulgence of their senses. Luxury goods are premium goods with high quality products, aesthetic design supported by excellent service, purchased by people from the higher income bracket (Cheng, 2006). In the earlier days the term 'luxury' was applied to products that were rare and scarce and available to a small segment of the people (Sriviroj, 2007). The luxury items were out of reach of the ordinary people and considered rare. Today the luxury product market has increased manifold. The young are spontaneously aware of the luxury brands which reflect their desires and fantasies and these brands provide them with social status, comfort, good quality and self- esteem.

2.2 Purchase behavior of young consumers for luxury products: Srichan Sriviraj et al. (2007) has studied the consumer behavior of young consumers towards purchase of luxury products in three countries namely the United Kingdom, Thailand and China. The research shows that UK and Thai respondents do not purchase products to show status or for possessive reasons; however, some Chinese respondents have bought luxury products to achieve status in society. There is hardly any relation of gender and purchase of luxury brand products. In terms of motivation, this research has suggested that the Snob, Perfectionist, and Hedonic effect motivate UK and Thai consumers into purchasing luxury products. Luxury consumers in China buy luxury brands as they are motivated by the Hedonic and Perfectionist value of luxury brands. This study focuses on 
three particular type of ethnic origin (UK, China, and Thailand); therefore, the results may be inapplicable to other groups of ethnicity.

Husic et al. (2009) studied the luxury market to understand the various factors that influence the purchase of luxury brands. The results show that in this market, luxury consumers feel that quality is an important attribute of luxury brands. There is a 'snob effect' observed among the consumers because they want to buy unique and exclusive product so that they can differentiate themselves from others. This paper highlights two sub-categories, namely "old aristocracy" and "new money" and a developing economy like India has more people in the 'new money' segment. It is also observed that the behavior of luxury consumers remains more or less similar across countries.

Parker (2010) studied the latent demand for luxury goods across India. It showed how the demand is divided and concentrated across the cities and regional markets of India.

Truong et al. (2010) explains that people with intrinsic orientation do not show a preference for buying luxury brands. The advertising campaigns of luxury brand companies are aimed at people with extrinsic orientation. Hence they could be ignoring consumers with intrinsic orientation, who do not identify themselves with these ads. Hence luxury brand companies should see how to reach these consumers with intrinsic orientation and at the same time they should maintain a good relationship with consumers of extrinsic orientation who buy luxury brands because of conspicuous consumption.

Kamolwan Tovikkai, Wiwatchai Jirawattananukool et al. (2010) have conducted a study to see the influence of individual value, achievement of status in society and demographic variables on purchase of luxury fashion brands by Thai female students. Quantitative research method via survey was used for this research. Data was collected by using survey questionnaires. The results show that there are two factors which have an important role in determining the purchase intentions of Thai female students on luxury fashion brands. One of them is achievement of social status and the other is attaining personal values like hedonic value and uniqueness value. It is seen that ethnocentrism is not having any influence on purchase of luxury fashion products in Thailand.

Qin Bian et al. (2010) researched that luxury brands are associated with "indulgence of the senses, regardless of price. Consumers buy luxury brands primarily for symbolic reasons to reflect their status and social goals. Luxury brands have a low ratio of functional utility to price and high ratio of intangible utility to price. Since luxury is a subjective concept, the perception of consumers about luxury brands will differ for different market segments.

Sinha et al. (2011) showed that urban youth are the major sources of luxury product consumption. They have less liabilities in the early part of their careers and so have a higher tendency to buy luxury brands. However, Indian luxury consumers are also value conscious and are on the hunt for stylist and aesthetically appealing products which are complimentary in nature. The key challenge is to educate the customers about the luxury industry.

According to A.T.Kearney (2011) report, luxury consumers follow global trends and hence luxury brand companies are using digital and social media to connect with these consumers.

Mishra (2011) examined the relationship between materialism and consumption innovativeness among urban Indian. The study tried to establish the fact that more materialistic Indian consumers tend to possess greater consumption innovativeness in comparison to the less materialistic consumers.

Haataja, Maria et al. (2011) have used qualitative data collection techniques with open ended questions to analyze the knowledge, opinions, personal tastes and style, thoughts and feelings of the respondents with respect to the luxury sector. According to the study, luxury goods were generally perceived as something expensive, unique, exclusive and something extra often having a brand name. The gap in the study could be the absence of data to assess the attitudes of young consumers with respect to brand extensions and diversifications. In the study by Haataja Maria (2011), high price and good quality were considered as two main attributes of luxury products. Around two-thirds of the respondents had a positive attitude towards purchase of luxury products. By the level of consumption, purchase intentions in the future and the attitudes to luxury the respondents can be divided into four groups: hard, regular, potential and non-interested luxury consumers.

The study further shows that the student population though currently can't afford the luxury products, but do desire them. They are well aware about the various brands and their niches.

MSL China et al (2011) researched and said that young women in China buy luxury products because of the following endorsements, social media, living for the moment, status symbol, love for material goods, hate counterfeits, peer pressure, etc. The market segmentation has been divided into desktop Cinderella's, trench coat tigers and golden dolls.

Gupta (2012) in his paper explains that the preference of people towards foreign brands can be different for different demographic segments. This is also influenced by demographic variables like age, gender, income and education. 
Luxe Avenue Publication et al (2012) in their research have pointed out a conflicting relationship between Generation Y using social media and luxury brands. According to them, the youth buy luxury brands not just for the feeling of luxury but also to make their dreams of an aspirational lifestyle come true. It also reveals how millennials are strongly influenced by peer pressure. All millennials were born in a more transparent universe due to easier communication thanks to technology. Hence they are very interested in enhancing their image among their peers. They generally value a "Just Do It" attitude. Luxury brand companies should target their marketing campaigns to the consumers rather than just the product. It is also found that luxury should not be perceived as merely expensive products only bought by old snobs, but as an experience which could help fulfil the Millennia's' desire for a deeper meaning of life. The current generation are mostly influenced by posts on social media and other online media. So, the marketing campaigns to attract them should be people-centred rather than a product-centred approach. This will help the Generation-Y market to keep growing with increasing buying power.

\section{Objectives}

1. To study the attitudes of young Indian consumers for purchase of luxury brands.

2. To understand how demographic variables like gender, age, income and occupation are related to various types of luxury value like social value, uniqueness value and quality value.

\section{Methodology:}

4.1Research design: This study aims to identify the attitude of young people towards luxury products. To carry out this research, we opted for a quantitative research design. A mix of both primary as well as secondary data has been used for the research.

The Internet and the World Wide Web are rapidly increasing in importance as sources of secondary data in business and management research.

We have used a structured questionnaire with closed ended questions.

The participants involved in this activity are from the age group of 18-35 years.

The participants were mostly college students or professionals, belonging to middle and upper middle class and both the genders.

4.2 Sample Design: The sample size is 500 people belonging to age group 18-35 years and residing in Mumbai and Navi Mumbai. The participants were mostly college students or professionals, belonging to middle and upper middle class and both the genders. This sample has been taken by non- random sampling method.

4.3 Data collection: A structured questionnaire with closed ended questions is used to collect the data 4.4 Data analysis: The collected data is analyzed using various quantitative tools like chi square test and finding the average ratings.

\section{(i) Descriptive Statistics}

\section{Analysis of data}

Table 1: Demographic Profile Analysis

\begin{tabular}{lll}
\hline Gender & Male $67 \%$ & Female $33 \%$ \\
\hline Age & $<25 \quad 48 \%$ & $25-3552 \%$ \\
Occupation & Students $33 \%$ & Professional $47 \%$ \\
Marital Status & Single $70 \%$ & Married $30 \%$ \\
Education & College $97 \%$ & Postgraduate $60 \%$ \\
Monthly Income & Starting from Rs. 50000 to more than Rs. & \\
& 5 lakhs & \\
\hline
\end{tabular}

\begin{tabular}{|l|r|}
\hline Statement & Mean \\
\hline If I buy luxury goods I will buy those known by many people & 3.43 \\
Luxury goods are a symbol of social status & 3.20 \\
I lose interest in luxury goods consumed by general population & 3.10 \\
Purchasing luxury goods helps enhance one's image & 3.30 \\
Purchasing luxury goods is a reward for effort and achievement & 3.33 \\
Consumption of luxury goods is an indication of successful people & 3.01 \\
Consumption of luxury goods reflects affluent lifestyle & 3.60 \\
Product's superior quality is my reason for buying luxury goods & 3.69 \\
My decision for purchase affected by quality and not others preference' & 3.92 \\
Product' superior quality is my reason to buy them & 3.73 \\
Consumers experience gratification and satisfaction by purchasing & 3.73 \\
Unique value of luxury goods & 3.73 \\
Social value of luxury goods & 3.53 \\
Quality value of luxury goods & 4.25 \\
I feel under pressure to buy luxury goods & 2.53 \\
\hline
\end{tabular}


People who are important to me influence me to purchase luxury goods

My friend would prefer me purchasing luxury brands

The influence of spokesperson makes me buy luxury goods

My colleagues have influenced me to purchase luxury goods

(ii) Formulation and testing of hypotheses:

1.Ho: There is no relation between age and unique value of luxury goods

$\mathrm{H1}$ : There is a relation between age and unique value of luxury goods

Chi-Square Tests: Unique value of luxury goods vs age

\begin{tabular}{|l|r|r|r|}
\hline & Value & Df & Asymp. Sig. (2-sided) \\
\hline Pearson Chi-Square & 26.226 & 12 & .010 \\
Likelihood Ratio & 17.282 & 12 & .139 \\
Linear-by-Linear Association & 4.951 & 1 & .026 \\
N of Valid Cases & 100 & & .026 \\
\hline
\end{tabular}

Since the significance value $<0.05$, we reject Ho and conclude that there is a relation between age and unique value of luxury goods.

2. H0: There is no relation between gender and unique value of luxury goods

$\mathrm{H1}$ : There is a relation between gender and unique value of luxury goods

Chi-Square Tests: unique value of luxury goods vs gender

\begin{tabular}{|l|r|r|r|}
\hline & Value & Df & Asymp. Sig. (2-sided) \\
\hline Pearson Chi-Square & 2.373 & 4 & .668 \\
Likelihood Ratio & 2.767 & 4 & .598 \\
Linear-by-Linear Association & .428 & 1 & .513 \\
N of Valid Cases & 100 & 1 & \\
\hline
\end{tabular}

Since the significance value $>0.05$, we accept Ho and conclude that there is no relation between gender and unique value of luxury goods.

3. H0: There is no relation between occupation and unique value of luxury goods

H1: There is a relation between occupation and unique value of luxury goods

Chi-Square Tests: Unique value of luxury goods vs occupation

\begin{tabular}{|l|r|r|r|}
\hline \multicolumn{2}{|c|}{ Chi-Square Tests: Unique value of luxury goods vs occupation } \\
\hline Pearson Chi-Square & Value & Df & Asymp. Sig. (2-sided) \\
Likelihood Ratio & 8.798 & 12 & .720 \\
Linear-by-Linear Association & 8.322 & 12 & .760 \\
N of Valid Cases & .528 & 1 & .467 \\
\hline
\end{tabular}

Since the significance value $>0.05$, we accept Ho and conclude that there is no relation between occupation and unique value of luxury goods.

4. H0: There is no relation between family income and unique value of luxury goods

$\mathrm{H} 1$ : There is a relation between family income and unique value of luxury goods

Chi-Square Tests: Unique value of luxury goods vs family income

\begin{tabular}{|l|r|r|r|}
\hline \multicolumn{2}{|c|}{ Chi-Square Tests: Unique value of luxury goods vs family income } & Df & Asymp. Sig. (2-sided) \\
\hline Pearson Chi-Square & Value & 8 & .825 \\
Likelihood Ratio & $4.341^{2}$ & 8 & .813 \\
Linear-by-Linear Association & 4.468 & .023 & .878 \\
N of Valid Cases & 100 & 1 & .878 \\
\hline
\end{tabular}

Since the significance value $>0.05$, we accept Ho and conclude that there is no relation between family income and unique value of luxury goods.

5. H0: There is no relation between age and quality value of luxury goods

H1: There is a relation between age and quality value of luxury goods 


\begin{tabular}{|l|r|r|r|}
\hline \multicolumn{1}{|c|}{ Chi-Square Tests: Quality value of luxury goods vs age } \\
\hline \multicolumn{1}{|c|}{ Value } & Df & Asymp. Sig. (2-sided) \\
\hline Pearson Chi-Square & 15.980 & 12 & .192 \\
Likelihood Ratio & 10.294 & 12 & .590 \\
Linear-by-Linear Association & .541 & 1 & .462 \\
N of Valid Cases & 100 & & \\
\hline
\end{tabular}

Since the significance value $>0.05$, we accept Ho and conclude that there is no relation between age and quality value of luxury goods.

6. H0: There is no relation between gender and quality value of luxury goods

H1: There is a relation between gender and quality value of luxury goods

Chi-Square Tests: Quality value of luxury goods vs gender

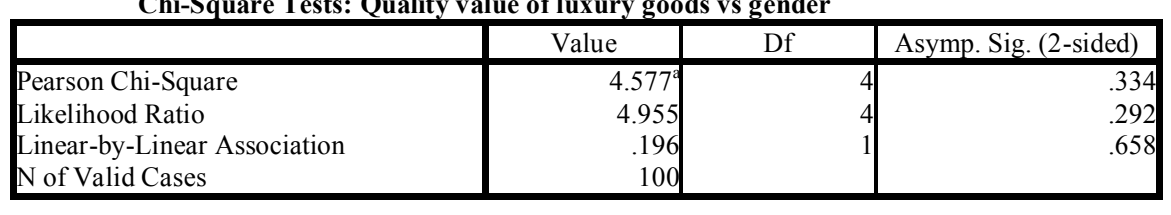

Since the significance value $>0.05$, we accept Ho and conclude that there is no relation between gender and quality value of luxury goods.

7. H0: There is no relation between occupation and quality value of luxury goods

$\mathrm{H} 1$ : There is a relation between occupation and quality value of luxury goods

Chi-Square Tests: Quality value of luxury goods vs occupation

\begin{tabular}{|l|r|r|r|}
\hline \multicolumn{4}{|c|}{ Chi-Square Tests: Quality value of luxury goods vs occupation } \\
\hline Pearson Chi-Square & Value & Df & Asymp. Sig. (2-sided) \\
Likelihood Ratio & 30.616 & 12 & .002 \\
Linear-by-Linear Association & 22.377 & 12 & .034 \\
N of Valid Cases & .897 & 1 & .344 \\
\hline
\end{tabular}

Since the significance value $<0.05$, we reject $\mathrm{Ho}$ and conclude that there is a relation between occupation and quality value of luxury goods.

8. H0: There is no relation between family income and quality value of luxury goods

H1: There is a relation between family income and quality value of luxury goods

Chi-Square Tests: quality value of luxury goods vs family income

\begin{tabular}{|c|c|c|c|}
\hline & Value & Df & Asymp. Sig. (2-sided) \\
\hline Pearson Chi-Square & $5.795^{3}$ & 8 & .670 \\
\hline Likelihood Ratio & 6.687 & 8 & .571 \\
\hline Linear-by-Linear Association & .026 & 1 & .873 \\
\hline $\mathrm{N}$ of Valid Cases & 100 & & \\
\hline
\end{tabular}

Since the significance value $>0.05$, we accept Ho and conclude that there is no relation between family income and quality value of luxury goods.

9. H0: There is no relation between age and social value of luxury goods

H1: There is a relation between age and social value of luxury goods

\begin{tabular}{|l|r|r|r|}
\hline \multicolumn{1}{|c|}{ Chi-Square Tests: Social value of luxury goods vs age } \\
\hline Pearson Chi-Square & Value & Df & Asymp. Sig. (2-sided) \\
Likelihood Ratio & 14.861 & 12 & .249 \\
Linear-by-Linear Association & 13.946 & 12 & .304 \\
N of Valid Cases & .105 & 1 & .745 \\
\hline
\end{tabular}

Since the significance value $>0.05$, we accept Ho and conclude that there is no relation between age and social value of luxury goods.

10. H0: There is no relation between gender and social value of luxury goods

H1: There is a relation between gender and social value of luxury goods 


\begin{tabular}{|c|c|c|c|}
\hline & Value & $\mathrm{Df}$ & Asymp. Sig. (2-sided) \\
\hline $\begin{array}{l}\text { Pearson Chi-Square } \\
\text { Likelihood Ratio } \\
\text { Linear-by-Linear Association } \\
\text { N of Valid Cases }\end{array}$ & $\begin{array}{r}.678^{\mathrm{a}} \\
.682 \\
.000 \\
100\end{array}$ & $\begin{array}{l}4 \\
4 \\
1\end{array}$ & $\begin{array}{r}.954 \\
.953 \\
.988\end{array}$ \\
\hline
\end{tabular}

Since the significance value $>0.05$, we accept Ho and conclude that there is no relation between gender and social value of luxury goods.

11. H0: There is no relation between occupation and social value of luxury goods

H1: There is a relation between occupation and social value of luxury goods

\begin{tabular}{|l|r|r|r|}
\hline \multicolumn{3}{|c|}{ Chi-Square Tests: Social value of luxury goods vs occupation } \\
\hline Pearson Chi-Square & Value & Df & Asymp. Sig. (2-sided) \\
Likelihood Ratio & 7.844 & 12 & .797 \\
Linear-by-Linear Association & 9.555 & 12 & .655 \\
N of Valid Cases & .065 & 1 & .798 \\
\hline
\end{tabular}

Since the significance value $>0.05$, we accept $\mathrm{Ho}$ and conclude that there is no relation between occupation and social value of luxury goods.

12. H0: There is no relation between family income and social value of luxury goods

H1: There is a relation between family income and social value of luxury goods

Chi-Square Tests: Social value of luxury goods vs family income

\begin{tabular}{|c|c|c|c|}
\hline & Value & Df & Asymp. Sig. (2-sided) \\
\hline Pearson Chi-Square & $11.634^{d}$ & 8 & .168 \\
\hline Likelihood Ratio & 13.145 & 8 & .107 \\
\hline Linear-by-Linear Association & .161 & 1 & 689 \\
\hline $\mathrm{N}$ of Valid Cases & 100 & & \\
\hline
\end{tabular}

Since the significance value $>0.05$, we accept Ho and conclude that there is no relation between family income and social value of luxury goods.

(iii) Some other descriptive Statistics

What is a luxury product in your opinion

\begin{tabular}{|ll|r|r|r|r|}
\hline & Frequency & \multicolumn{1}{c|}{ Percent } & Valid Percent & Cumulative Percent \\
\hline \multirow{4}{*}{ Great comfort items } & 110 & 22.0 & 22.0 & 22.0 \\
Best quality items & 125 & 25.0 & 25.0 & 47.0 \\
Extravagant items & 90 & 18.0 & 18.0 & 65.0 \\
Very Selective \& exclusive items & 140 & 28.0 & 28.0 & 93.0 \\
Expensive but unnecessary items & 35 & 07.00 & 07.00 & 100.0 \\
Total & 500 & 100.0 & 100.0 & \\
\hline
\end{tabular}

Inference: $28 \%$ of the sample population is of the opinion that luxury goods are very selective and exclusive items. There seems to be no connection between the age and the opinion of a luxury brand.

\begin{tabular}{|ll|r|r|r|r|}
\hline & How often do you buy luxury brands \\
\hline & Frequency & Percent & Valid Percent & Cumulative Percent \\
\hline \multirow{4}{*}{ Valid } & 125 & 25.0 & 25.0 & 25.0 \\
& Every six months & 25 & 5.0 & 5.0 & 30.0 \\
& Monthly & 350 & 70.0 & 70.0 & 100.0 \\
once in a year & 500 & 100.0 & 100.0 & \\
Total & &
\end{tabular}

Inference: Luxury bands are purchased once a year, supporting the claim that they are selective and exclusive and therefore cannot be purchased in a highly regular pattern. 


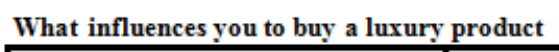

\begin{tabular}{|l|r|r|r|r|r|}
\hline & Frequency & Percent & Valid Percent & Cumulative Percent \\
\hline & Friends & 95 & 19.0 & 19.0 & 19.0 \\
Family & 10 & 2.0 & 2.0 & 21.0 \\
Celebrities & 20 & 4.0 & 4.0 & 25.0 \\
& Myself & 195 & 39.0 & 39.0 & 64.0 \\
Valid & Advertisements & 85 & 17.0 & 17.0 & 81.0 \\
& Social Status & 90 & 18.0 & 18.0 & 99.0 \\
& Other & 5 & 1.0 & 1.0 & 100 \\
& & & & & \\
& & & & & \\
& & & & & \\
& & & & & \\
\end{tabular}

\begin{tabular}{|ll|r|r|r|r|}
\hline \multicolumn{2}{|c|}{ From where do you buy luxury brands } & Valid Percent & Cumulative Percent \\
\hline & Speciality Stores & 135 & 26.59 & 26.59 & 26.59 \\
Malls & 285 & 58.51 & 58.51 & 85.1 \\
Valid & Company Outlets & 55 & 11.70 & 11.70 & 96.8 \\
& Company Exhibitions & 5 & 1.06 & 1.06 & 97.86 \\
& Other & 20 & 2.12 & 2.12 & 100 \\
& & & & & \\
& & & & & \\
Total & & & & \\
\end{tabular}

Inference : Clearly luxury products are bought for oneself and one's own pleasure. Influence of friends exists in this demographic too.

Inference : Malls are the place where people prefer to buy luxury brands.

\begin{tabular}{|l|r|r|r|r|r|r|}
\hline & $\mathrm{N}$ & $\begin{array}{c}\text { Minim } \\
\text { um }\end{array}$ & Minimum & Maximum & Mean & Std. Deviation \\
\hline The brand has a strong image & 500 & 1.00 & 1.00 & 5.00 & 1.7340 & 0.9473 \\
The brand has strong online presence & 500 & 1.00 & 1.00 & 5.00 & 2.6383 & 1.02988 \\
The brand provides the best quality & 500 & 1.00 & 1.00 & 5.00 & 1.5699 & 0.7951 \\
The brand is expensive & 500 & 1.00 & 1.00 & 5.00 & 2.3404 & 1.1444 \\
The brand has great looks or aesthetic & 500 & 1.00 & 1.00 & 5.00 & 1.6489 & 0.8593 \\
appeal & 500 & 1.00 & 1.00 & 5.00 & 2.2979 & 1.0193 \\
The brand has great history & 500 & 1.00 & 1.00 & 5.00 & 2.8404 & 1.1877 \\
The brand has a celebrity endorser & 500 & 1.00 & 1.00 & 5.00 & 1.7053 & 0.9611 \\
\hline It makes me feel good & & & & & \\
\hline
\end{tabular}

From the Descriptive Statistics mentioned above on the factors affecting luxury goods. The top 3 are as follows:

1. The brand provides the best quality(which is consistent with the opinion of luxury goods)

2. The brand has great looks or aesthetic appeal(consistent with the opinion that luxury goods are exclusive items)

3. The brand has a strong brand image

From the mean ratings, it is found that

\section{Findings}

1. Consumption of luxury goods reflects affluent lifestyle.

2. The product's superior quality is the main reason for buying luxury goods. Quality is one of the important aspects of the functional value of a luxury brand. The quality of raw materials used and the excellent workmanship of the employees contribute to the functional value which is a very important dimension of luxury.

3. Consumers experience gratification and satisfaction by purchasing luxury goods. Luxury brands have good looks or aesthetics which is an important motivation for consumers to buy luxury brands. They derive pleasure and hedonic value by consumption of these brands. It gives them a feeling of happiness, relieves them of stress and makes them feel good.

4. They have a high rating for unique value of luxury goods. Luxury consumers want to buy goods which are rare and exclusive. They should have products which are not possessed by many. These products are not mass-produced. The luxury buyers stop buying these products when they become common among other people. 
5. They have a high rating for social value of luxury goods. People want to conform to a group by buying luxury goods. They want others to admire them because of their social status. They want to segregate themselves from people of lower strata by buying such products.

6. They have maximum rating for quality value of luxury goods.

7. The other findings are:

8. There is a relation between age and unique value of luxury goods. People with a higher age are more concerned about the uniqueness value of luxury goods. As they become older, they rise in terms of their position at the job and want to position themselves apart from others. So they want to buy those luxury products which are not possessed by others.

9. There is no relation between gender and unique value of luxury goods. It has been observed that both men and women are similar in their perception of uniqueness value of luxury goods.

10. There is no relation between occupation and unique value of luxury goods. People of all occupations whether professionals, business people or homemakers want to possess luxury goods which set them apart from others.

11. There is no relation between family income and unique value of luxury goods. People of all income groups want to buy luxury goods which are not possessed by others.

12. There is no relation between age and quality value of luxury goods. People of all groups want that the luxury products that they buy should have excellent quality, they should be durable, with good looks and should last a lifetime.

13. There is no relation between gender and quality value of luxury goods. Both men and women are similar in their perception of quality value of luxury goods.

14. There is a relation between occupation and quality value of luxury goods. Professionals are more interested in quality value of luxury goods, possibly because of a higher awareness of the efforts and materials that go into making a luxury product.

15. There is no relation between family income and quality value of luxury goods. People of all income groups consider that the luxury product should have excellent quality, should have high usability, aesthetics and have a good brand image.

16. There is no relation between age and social value, gender and social value, occupation and social value and family income and social value of luxury goods. This means that people of all age groups, gender, occupations and income groups want to buy luxury products to conform to the upper social classes and to segregate themselves from the masses.

17. The main perception that consumers have of luxury brands is that they are very selective and exclusive items and are best quality items.

18. Luxury bands are purchased mainly once a year, since they are premium priced goods and also selective and exclusive.

19. Luxury products are bought mainly for oneself and one's own pleasure. Young people are influenced by friends in purchase of luxury brands, wheras older people could be more influenced by family.

20. Malls and speciality stores are the place where people prefer to buy luxury brands.

21. The consumers feel that luxury brands should have best quality, great looks or aesthetic appeal and a strong brand image.

\section{Benefits of the study}

This study will help luxury brand companies to target young Indian customers who want to buy luxury brands because of their brand image, exclusivity and excellent quality. It helps the companies to understand how consumers perceive luxury brands and what features are considered most important by them. It also helps them to understand how luxury brands with high quality, uniqueness and social value will appeal to people of different age groups, occupations, income groups and gender.

\section{Managerial implications}

The results of this research have practical implications for marketers working in the luxury industry. The results suggest that a focus on designing and managing optimal products together with exclusivity can create positive emotions. To effectively react to the needs, wants and values of purchasers is vital, especially in an increasingly competitive global marketplace. Positioning and segmentation decisions have to be made on a global level. Companies should inform consumers about the high quality materials and handcrafting of luxury products and emphasize a unique, quality product. Consumer education can transpire in the form of advertising that stresses quality and/or labels, packaging, and supplementary facts that offer comprehensive information on genuine luxury products. Managers of luxury goods should emphasize the positive, functional, aesthetic and emotional experience of owning and using a luxury product. Knowledge and understanding of these differences and similarities can help in designing suitable marketing campaigns. From a market positioning perspective, 
monitoring the evaluative criteria of consumers can help marketers to recognize and focus on the specific luxury dimensions.

\section{Limitations and scope for further research}

Firstly, the study has been done only for young luxury consumers in the age group of 18-35 years. It can be extended to people of other age groups also. Secondly, the study can be done with respect to a particular luxury product category. Thirdly, the sample has been taken only from Mumbai and Navi Mumbai. The results can be different if the sample is taken from other urban areas or rural areas. All these can be the scope for further research.

Firstly,a particular limitation of this study was that the respondents were all from Mumbai and Navi Mumbai and represented only one specific demographic group i.e. urban people of India. Secondly, the study has been done only for young luxury consumers in the age group of 18-35 years. Thus, the results might vary if this study was repeated in different cities or regions of India or people of other age groups. In terms of further research, therefore, researchers should consider expanding the study focus to different areas and different populations.

Thirdly, the sample size taken is small which may not be a very good representation of the population.

Fourthly, only the overall perceptions about luxury value have been tested. We can apply similar analysis for a specified luxury product or service.

Fifthly, the study has limitations of time and experience available with the researcher.

Lastly, this study employed non-probability sampling method. This method does not ensure that each unit will has anequal chance of being selected as in probability sampling; therefore, such samples are vulnerable to selection biases. Therefore the study result may not represent the whole social class and test results may only apply to the participating respondents.

This becomes the scope for further research.

\section{References}

[1]. A.T Kearney (2010), 'Luxury in India: charming the snakes and scaling the ladders', New Delhi.

[2]. A.T. Kearney (2011) "India Luxury Review 2011”, October, New Delhi.

[3]. Attitude of young people towards luxury product (2011) at www.ibef.org

[4]. Berry, C. J. (1994), 'The idea of luxury: a conceptual historical investigation', Cambridge, UK: Cambridge University Press.

[5]. Cornell, A. (2002), "Cult of Luxury: The New Opiate of the Masses", Australian Financial Review, pp. 47

[6]. Danziger, P. N. (2005). Let them eat cake: Marketing luxury to the masses - as well as the classes. Chicago, IL: Dearbourn Trade Publishing.

[7]. Dubois, B., Czellar, S., \& Laurent, G. (2001). Consumer rapport to luxury: Analyzing complex and ambivalent attitudes. HEC School of Management. Retrieved from http://www.hec.fr/hec/fr/professeurs-recherche/upload/cahiers/CR736.pdf

[8]. Dubois, B. \& Laurent, G. (1994), "Attitudes Toward the Concept of Luxury: An Exploratory Analysis," in Asia-Pacific Advances in Consumer Research, Siew Meng Leong and Joseph A. Cote (eds.), Singapore, 1(2) : 273-278.

[9]. Gupta, N. (2011) "Globalization Does Lead To Change In Consumer Behavior: An Empirical Evidence Of Impact Of Globalization On Changing Materialistic Values In Indian Consumers And Its After Effects”, Asia Pacific Journal Of Marketing And Logistics, Vol. 23(3), Pp $251-269$.

[10]. Gupta N. (2012) "The Impact Of Globalization On Consumer Acculturation: A Study Of Urban Educated, Middle Class Indian Consumers", Asia Pacific Journal Of Marketing And Logistics, Vol. 24(1), pp. 41.58

[11]. Haataja, Maria et al (2011), 'Attitudes of young people towards luxury products'.

[12]. Husic M and Cicic, M. (2009) "Luxury Consumption Factors”,Journal Of Fashion Marketing And Management, Vol. 13(2), pp. 231-245

[13]. Kamolwan Tovikkai, Wiwatchai Jirawattananukool et al (2010), 'An exploratory study on young Thai women consumer behavior toward purchasing luxury fashion brands'.

[14]. Kapferer, J-N. (2001), Reinventing the Brand: Can Top Brands Survive the New Market Realities? Kogan Page, Milford, CT.

[15]. Kapferer, Jean-Noel; Michaut, Anne (2014), 'Luxury counterfeit purchasing: The collateral effect of luxury brands' trading down policy', Journal of Brand Strategy, 3 (1) : 59-70

[16]. Nia, A. \& Zaichkowsky, J.L. (2000). Do counterfeits devalue the ownership of luxury brands?, Emerald Journal, 9 (7): $485-497$

[17]. Pantzalis, I. (1995). Exclusivity strategies in pricing and brand extension. Unpublished doctoral dissertation. Tucson: University of Arizona.

[18]. Parker , R.S, Hermans, C.M and Schaefer,A.D. (2004), 'Fashion Consciousness of Chinese, Japanese and American teenagers', Journal of Fashion Marketing and Management, 8(2): 176-186

[19]. Phau, I., \& Prendergast, G. (2000). Consuming Luxury Brands: The Relevance of the 'Rarity Principle'. Journal of Brand Management, 8(2): 122-138.

[20]. Qin Bian (2010, 'Examining of U.S and Chinese students purchase intention for luxury brands'

[21]. Sinha, D (2010), 'Consumer India: Inside the Indian mind and wallet', Singapore: John Wiley \& Sons.

[22]. Srichan Sriviroj (2007), 'Purchasing Luxury Goods:Consumer behavior of international students in the UK'

[23]. Truong Y, Simmons G, McColl r., Kitchen, P.J.(2008), ' Status and conspicuousness-Are they related? Strategic marketing implications for luxury brands', Journal of Strategic Marketing, 16(3):189-203

[24]. Vigneron, F. \& Johnson, W.L. (1999), “A Review and a Conceptual Framework of Prestige-Seeking Consumer", Academy of Marketing Science, No. 1, pp. 1-15.

[25]. Vigneron, F., \& Johnson, L. W. (2004). Measuring perceptions of brand luxury. Journal of Brand Management, 11(6) : $484-506$.

[26]. Wiedmann, K. P., Hennigs, N., \& Siebels, A. (2007), 'Measuring consumers' luxury value perception: A cross-cultural framework', Academy of MarketingScience Review, 2007(7). 